\title{
PROBLEMATIKA IMPLEMENTASI BANTUAN HUKUM DI INDONESIA
}

\author{
Oleh: \\ Achmad Al-Muhajir \\ STIS Al Maliki Bondowoso \\ Amsam7405@gmail.com
}

\begin{abstract}
:
Legal aid represent constitutional rights for every citizen in front of law which arranged in Act Number 16 Year 2011 concerning Legal Aid, specially to impecunious society (the poor). Researcher tries to investigate the problem of Legal Aid implementation in Indonesia. To answer the the problems used by method research of normatif yuridis, having the character of analytical descriptive, using justice theory, used data of sekunder of book study, with approach of legislation. Results of this research concluded that implementation giving of legal aid to the poor as arranged in Act Number 16 Year 2011 About Legal Aid not yet can walk it to, there still found by many resistance and constraint, like human resource factor related to amount and quality giver of legal aid, and related/relevant culture factor society itself the lack of knowledge of society about legal aid. Potency receiver of its amount legal aid very big, but run legal aid system in this time not yet as according to real requirement to legal aid. Access to legal aid program to society still limited especially because its minim of existence of organization giver of legal aid or access inaccesible region geographically. Factor enforcer of less owning law of integrity, moralitas, and idealism of profesionalitas. Factor is lack of budget or financing of Local Government, and lack of observation and control.
\end{abstract}

Keyword: Problematika, Implementation, Legal Aid

\section{A. Pendahuluan}

Betapa pentingnya menjunjung tinggi harkat dan martabat manusia, sehingga negara dalam menjalankan tugas dan tanggungjawabnya wajib memelihara dan melindungi hak-hak dasar atau hak asasi warganya secara luas, tak terkecuali hak warga negara dalam hal perlindungan hukum dan/atau bantuan hukum, khususnya bagi kelompok masyarakat miskin dan/atau kelompok masyarakat yang termarginalkan.

Sebagai negara hukum sebagaimana tercantum dalam Pasal 1 ayat (3) UUD Negara Republik Indonesia Tahun 1945 menyatakan bahwa 
"Negara Indonesia adalah negara hukum", maka dalam menjalankan sistem ketatanegaraannya harus menerapkan prinsip-prinsip manajemen negara hukum. Salah satu ciri khas negara hukum adalah kedudukan yang sama dihadapan hukum dan perlindungan hukum yang sama (equality before the law and equal protection of law) bagi semua warga negara atau ada yang menyebutkan pula sebagai kedudukan yang sama dihadapan hukum dan penerapan hukum yang bebas dari status sosial (equality before the law, general application of the law independent from the social status of those concerned).

Bantuan hukum merupakan hak konstitusional setiap warga negara atas jaminan perlindungan hukum dan jaminan persamaan di depan hukum, sebagai sarana pengakuan hak asasi manusia (HAM). Mendapatkan bantuan hukum bagi setiap orang adalah perwujudan acces to justice (akses terhadap keadilan) sebagai implementasi dari jaminan perlindungan hukum, dan jaminan persamaan di depan hukum. Hal ini sesuai dengan konsep bantuan hukum yang dihubungkan dengan cita-cita negara kesejahteraan (welfare state).

Perwujudan dari prinsip kedudukan yang sama dihadapan hukum dan perlindungan hukum yang sama bagi semua warga negara adalah bahwa setiap warga negara yang sedang berhadapan dengan perkara hukum harus diberikan hak yang sama untuk memperoleh kemudahan akses untuk menyelesaikan perkaranya dan hak untuk didampingi oleh advokat guna menyelesaikan perkara hukumnya tersebut baik melalui jalur litigasi maupun nonlitigasi.

Pemberian bantuan hukum adalah salah satu perwujudan dari amanat Pasal 28D ayat (1) UUD 1945 yang menyatakan "setiap orang berhak atas pengakuan, jaminan, perlindungan, dan kepastian hukum yang adil serta perlakuan yang sama dihadapan hukum". UUD 1945 mengualifikasikan hak atas pengakuan, jaminan, perlindungan, dan kepastian hukum yang adil serta perlakuan yang sama dihadapan hukum sebagai bagian dari hak asasi manusia.

Penyebutan hak dalam UUD 1945 membawa konsekuensi tertentu, baik terhadap pengualifikasiannya maupun pihak mana yang memiliki kewajiban utama dalam pemenuhannya. Oleh karena disebutkan secara resmi dalam konstitusi, maka hak tersebut dikualifikasi sebagai hak konstitusional setiap warga negara. Sehingga pemegang kewajiban utama dalam pemenuhannya adalah negara ${ }^{1}$.

1 Jimly Asshiddiqy, Hak Konstitusional Perempuan dan Tantangan Penegakannya, disampaikan pada acara Dialog Publik dan Konsultasi Nasional Komnas Perempuan 342 JURNAL LISAN AL-HAL 
Jaminan terhadap hak dan kewajiban ini ditegaskan dan dijadikan landasan bagi pembentukan UU No. 16 Tahun 2011 tentang Bantuan Hukum. Dalam konsideran menimbang huruf a UU Bantuan Hukum dinyatakan bahwa Negara menjamin hak konstitusional setiap orang untuk mendapatkan pengakuan, jaminan, perlindungan, dan kepastian hukum yang adil serta perlakuan yang sama dihadapan hukum sebagai sarana perlindungan hak asasi manusia.

Prinsip perlakuan yang sama dihadapan hukum (equality before the law) adalah perwujudan negara hukum sebagaimana diatur dalam Pasal 1 ayat (3) UUD 1945. Pemenuhannya sangat penting dan fundamental, karena selain sebagai bentuk perlindungan dan persamaan dihadapan hukum, prinsip ini merupakan pilar utama dalam mewujudkan peradilan yang adil (fair trial).

Peradilan yang adil sangat sulit tercapai apabila para pihak tidak berada dalam kedudukan yang setara. Terlebih lagi, apabila pihak yang berhadapan dengan hukum (baik tersangka, terdakwa, saksi, maupun korban) menjadi objek dan bukan subjek dalam suatu proses peradilan. Hal ini semakin kompleks jika pihak yang berhadapan dengan hukum tersebut menyandang status orang miskin (the poor). Di satu sisi, akses kaum miskin terhadap keadilannya (access to justice) rentan terabaikan atau sengaja diabaikan. Di sisi lain, akses terhadap keadilan masih menjadi salah satu persoalan utama bagi banyak orang yang berurusan dengan hukum. Penyebabnya banyak, pertama, karena minimnya informasi bagi masyarakat awam tentang proses hukum. Kedua, karena ketidakmampuan dan penolakan banyak orang atas maraknya praktek korupsi dan kolusi diproses hukum. Ketiga, karena ketidakprofesionalan aparat hukum saat berurusan dengan warga negara. Akibatnya kepercayaan masyarakat terhadap aparat hukum menurun, pelayanan hukum pun tidak optimal, dan sering terjadi kekerasan atau rekayasa bukti dalam proses penegakan hukum.

UU No. 16 Tahun 2011 tentang Bantuan Hukum memberi peluang terhadap perlindungan hak warga negara yang sedang menjalani proses hukum. Ada dua latar belakang yang menjadi dasar pembentukan UU Bantuan Hukum, yaitu (i) jaminan negara terhadap hak konstitusional setiap orang untuk mendapatkan pengakuan, jaminan, perlindungan dan kepastian hukum yang adil serta perlakuan yang sama dihadapan hukum

"Perempuan dan Konstitusi di Era Otonomi Daerah: Tantangan dan Penyikapan Bersama”, Jakarta, 27 November 2007. 
sebagai sarana perlindungan HAM, (ii) negara bertanggungjawab terhadap pemberian bantuan hukum bagi orang miskin sebagai perwujudan akses terhadap keadilan. Bantuan hukum yang dimaksud dalam UU Bantuan Hukum adalah jasa hukum yang diberikan oleh pemberi bantuan hukum yaitu lembaga bantuan hukum atau organisasi yang memberikan layanan bantuan hukum secara cuma-cuma kepada penerima bantuan hukum².

Menurut UU Bantuan Hukum, penyelenggaraan bantuan hukum bertujuan untuk:

a. Menjamin dan memenuhi hak bagi penerima bantuan hukum untuk mendapatkan akses terhadap keadilan;

b. Mewujudkan hak konstitusional segala warga negara sesuai dengan prinsip persamaan kedudukan di dalam hukum;

c. Menjamin kepastian penyelenggaraan bantuan hukum dilaksanakan secara merata di seluruh wilayah negara Indonesia; dan

d. Mewujudkan peradilan yang efektif, efisien, dan dapat dipertanggungjawabkan ${ }^{3}$.

Secara garis besar, tujuan bantuan hukum yang tercantum dalam Pasal 3 UU Bantuan Hukum tersebut adalah mewujudkan akses kepada keadilan bagi masyarakat miskin dan juga mewujudkan peradilan yang efektif, efisien, dan dapat dipertanggungjawabkan (akuntabel). Jadi bantuan hukum tidak semata untuk memberikan jasa hukum bagi masyarakat akan tetapi sekaligus diharapkan mampu mendorong perbaikan sistem peradilan.

Bantuan hukum diharapkan mampu menjadi sistem yang membantu melindungi hak masyarakat dalam proses hukum untuk memperoleh keadilan melalui sistem peradilan yang transparan dengan menerapkan prinsip perlindungan Hak Asasi Manusia (HAM). Kondisi saat ini menunjukkan adanya relevansi antara bantuan hukum dengan penegakan perlindungan HAM dalam proses hukum.

Implementasi bantuan hukum akan menghadapi berbagai permasalahan dalam penegakan hukum di Indonesia mulai dari kendala regulasi, profesionalisme aparat, dan pemahaman masyarakat dalam mengakses hak-hak mereka. Implementasi bantuan hukum berdasarkan UU Bantuan Hukum juga akan dihadapkan dan dipengaruhi sistem bantuan hukum yang ada sebelum UU Bantuan Hukum diterapkan. Bantuan hukum bukan merupakan mekanisme baru dalam sistem penegakan hukum di Indonesia. Bantuan hukum secara tegas diatur dalam

2 Lihat Pasal 1, Pasal 2 dan Pasal 3 UU Bantuan Hukum.

3 Pasal 3 UU Bantuan Hukum

$344 \mid$ JURNAL LISAN AL-HAL 
UU No. 14 Tahun 1970 tentang Pokok-Pokok Kekuasaan Kehakiman. Kemudian, pengaturannya dimuat dalam berbagai peraturan perundangundangan. Implementasi prosedur bantuan hukum yang diatur dalam berbagai peraturan perundang-undangan telah menciptakan prosedur/ sistem bantuan hukum yang telah diimplementasikan dalam waktu yang cukup lama. Sebagai contoh sistem Posbakum di pengadilan, bantuan hukum oleh organisasi bantuan hukum atau bantuan hukum oleh profesi advokat. Sistem yang sudah lama berjalan tersebut --dengan berbagai sistem pendukungnya--akan dihadapkan pada model baru yang mengacu pada ketentuan UU Bantuan Hukum.

Berbagai permasalahan dalam penegakan hukum dan peradilan tersebut akan menjadi tantangan bagaimana upaya implementasi UndangUndang ini dapat efektif dan mencapai tujuan yang telah dirumuskan. Oleh karena itu, efektivitas regulasi dan sistem bantuan hukum menjadi situasi yang perlu dipantau dalam mendorong perlindungan hak masyarakat yang sudah dijamin dalam undang-undang.

Pemantauan dilakukan dalam rangka mendorong perlindungan hak masyarakat dalam kerangka bantuan hukum tersebut dilakukan dalam bentuk kegiatan riset kebijakan. Kegiatan ini bukan merupakan evaluasi, mengingat implementasi bantuan hukum juga belum cukup lama. Riset ini lebih pada penilaian terhadap kebutuhan yang dapat diidentifikasi dari praktek pemberian bantuan hukum pada masa awal penerapannya. Sehingga identifikasi awal ini bisa menjadi masukan bagi perbaikan sistem bantuan hukum kedepan.

Riset ini juga untuk mendorong pencapaian tujuan bantuan hukum yaitu perlindungan HAM dan perbaikan sistem peradilan, khhususnya dalam rangka memberikan perlindungan dan jaminan penghormatan terhadap hak individu dalam proses hukum.

Mengingat pentingnya bantuan hukum dalam menciptakan keadilan, menegakkan HAM dan equality before the law, serta dalam mencapai due process of law, tentu menjadikan kewajiban pemberian bantuan hukum menjadi hal yang penting untuk dapat dilaksanakan secara efektif. Berdasarkan pemikiran di atas, penulis tertarik membahas terkait Implementasi Bantuan Hukum di Indonesia dan Problematikanya.

\section{B. Metode Penelitian}

Guna membahas permasalahan implementasi Bantuan Hukum, penulis menggunakan metode penelitian normatif, yaitu penelitian yang menggunakan bahan pustaka sebagai bahan penelitiannya. Pada penelitian hukum jenis ini, seringkali hukum dikonsepsikan sebagai apa yang tertulis 
dalam peraturan perundang-undangan (law in books) atau hukum dikonsepkan sebagai kaidah atau norma yang merupakan patokan berperilaku manusia yang dianggap pantas ${ }^{4}$.

Penelitian terhadap problematika pelaksanaan UU No. 16 Tahun 2011 tentang Bantuan Hukum dengan melihatnya dari sudut pandang pelaksanaan bantuan terhadap masyarakat miskin yang selama ini sudah dilaksanakan di Indonesia menggunakan pendekatan normatif5.

Penelitian ini kemudian masuk ke dalam penelitian yuridis normatif yang pada dasarnya melihat pada dua aspek, pembentukan hukum dan penerapan hukum, khususnya penerapan UU No. 16 Tahun 2011 tentang Bantuan Hukum dan juga memperbandingkannya dengan pelaksanaan bantuan hukum yang telah berjalan pada saat ini.

Oleh karena itu, pendekatan yang dilakukan adalah pendekatan yang bersifat analitis (analytical approach) yaitu untuk mengetahui makna yang ada dibalik Undang-Undang Bantuan Hukum, sekaligus mengkaitkannya dengan realitas pelaksanaan bantuan hukum dalam berbagai peraturan perundang-undangan yang sudah ada sebelum UU No. 16 Tahun 2011 diundangkan. Selain itu, karena penelitian ini juga akan menelaah berbagai peraturan perundang-undangan yang terkait dengan bantuan hukum maka digunakan juga pendekatan peraturan perundangundangan (statutory approach).

Penelitian juga melihat faktor empiris dengan memperbandingkan UU No. 16 Tahun 2011 tentang Bantuan Hukum dengan pelaksanaan bantuan hukum yang sudah berjalan saat ini, menggunakan teknik observasi dengan dilengkapi berbagai data serta ulasan mengenai pelaksanaan bantuan hukum yang telah ada saat ini.

Berkaitan dengan pendekatan-pendekatan di atas, maka pengambilan data dalam studi ini adalah melalui pengambilan berbagai data. Data-data tersebut meliputi data primer berupa peraturan perundang-undangan yang berkaitan dengan Bantuan Hukum dan data sekunder yang meliputi berbagai buku dan karya ilmiah lainnya yang terkait dengan bantuan hukum.

Dengan data dan bahan tersebut akan dilakukan pengolahan dan analisis data yang dilakukan dengan cara kualitatif dengan menekankan pada aspek hukum, historis dan empiris terhadap pelaksanaan pertauran

4 Amiruddin dan Zainal Asikin, Pengantar Metode Penelitian Hukum, (Jakarta: PT Raja Grafindo Persada, 2004), 118.

5 Johny Ibrahim, Teori dan Metodologi Penelitian Hukum Normatif, Surabaya: Bayumedia Publishing, 2006), 299-322.

346 JURNAL LISAN AL-HAL 
perundang-undangan yang telah dilaksanakan di Indonesia saat ini. Penelitian ini akan melakukan penilaian yang bersifat evaluatif terhadap beberapa pokok-pokok pengaturan yang ada dalam Undang-Undang Bantuan Hukum dengan pendekatan bantuan hukum struktural dan pendekatan bantuan hukum yang berbasis pemberdayaan hukum masyarakat. Dengan demikian, akan dapat diidentifikasi tantangan apa saja yang akan dihadapi dalam pelaksanaan Undang-Undang Bantuan Hukum ketika dihadapkan dengan pendekatan-pendekatan bantuan hukum yang sudah ada dalam masyarakat selama ini.

\section{Pembahasan}

\section{Pengertian Bantuan Hukum}

Menurut UU No. 16 Tahun 2011 tentang Bantuan Hukum, PP No. 42 Tahun 2013 tentang Syarat dan Tata Cara Pemberian Bantuan Hukum dan Penyaluran Dana Bantuan Hukum, dan Permenkumham No. 1 Tahun 2018 tentang Paralegal dalam Pemberian Bantuan Hukum yang ditandatangani Menteri Hukum dan Hak Asasi Manusia Yasonna H. Laoly pada 17 Januari 2018. Peraturan Menteri Hukum dan Hak Asasi Manusia No. 1 Tahun 2018 tentang Paralegal dalam Pemberian Bantuan Hukum diundangkan dalam Berita Negara Republik Indonesia Tahun 2018 Nomor 182 oleh Widodo Ekatjahjana Dirjen Peraturan Perundang-Undangan Kemenkumham RI pada 26 Januari 2018, di Jakarta, bahwa Bantuan Hukum adalah jasa hukum yang diberikan oleh Pemberi Bantuan Hukum secara cuma-cuma kepada Penerima Bantuan Hukum.

Dalam penyelenggaraan Bantuan Hukum, UU No. 16 Tahun 2011 tentang Bantuan Hukum ini memiliki tujuan dalam menyelenggarakan bantuan hukum yaitu seperti yang tercantum dalam Pasal 3 UU No. 16 Tahun 2011 tentang Bantuan Hukum, yaitu :

1. Menjamin dan memenuhi hak bagi penerimaan Bantuan Hukum untuk mendapatkan akses keadilan;

2. Mewujudkan hak konstitusional setiap warga negara sesuai dengan prinsip persamaan kedudukan di dalam hukum;

3. Menjamin kepastian penyelenggaraan Bantuan Hukum dilaksanakan secara merata di seluruh wilayah Negara Republik Indonesia; dan

4. Mewujudkan peradilan yang efektif, efisien, dan dapat dipertanggungjawabkan.

Istilah Bantuan Hukum sendiri dipergunakan sebagai terjemahan dari dua istilah yang berbeda yaitu "Legal Aid" dan "Legal Assistance". Istilah Legal Aid biasanya digunakan untuk pengertian bantuan hukum dalam arti sempit berupa pemberian jasa-jasa dibidang hukum kepada 
seseorang dalam suatu perkara secara cuma-cuma khususnya bagi mereka yang tidak mampu. Legal Assistence dipergunakan untuk menunjukkan pengertian bantuan hukum kepada mereka yang tidak mampu maupun pemberian bantuan hukum oleh para advokat yang menggunakan honorarium 6 .

Menurut Adnan Buyung Nasution ${ }^{7}$ bantuan hukum adalah: Legal aid, yang berarti pemberian jasa dibidang hukum kepada seseorang yang terlibat dalam suatu kasus atau perkara:

1) Pemberian jasa bantuan hukum dilakukan dengan cuma-cuma,

2) Bantuan jasa hukum dalam legal aid lebih dikhususkan bagi yang tidak mampu dalam lapisan masyarakat miskin,

3) Dengan demikian motivasi utama konsep legal aid adalah menegakkan hukum dengan jalan membela kepentingan hak asasi rakyat kecil yang tak punya dan buta hukum.

Bantuan Hukum dalam pengertian yang lebih luas dapat diartikan sebagai upaya unuk membantu golongan yang tidak mampu dalam bidang hukum. Menurut Adnan Buyung Nasution mengatakan; upaya untuk membantu golongan yang tidak mampu mempunyai tiga aspek yang paling berkaitan, yaitu aspek perumusan aturan-aturan hukum, aspek pengawasan terhadap mekanisme untuk menjaga agar aturan itu ditaati, dan aspek pendidikan masyarakat agar aturan-aturan itu dihayati.

Yang menjadi persoalan dalam hal ini adalah siapa yang dimaksud dengan masyarakat yang kurang mampu atau tidak mampu ?. Kita perhatikan uraian yang dikemukakan oleh Prof. Dr. Mochtar Kusumaatmadja “...... Pemberian bantuan hukum bagi orang-orang yang tidak mampu sama tuanya dengan profesi hukum itu sendiri. Hal ini dilakukan atas dasar amal dengan tujuan utama untuk memberikan kepada orang-orang tak mampu kesempatan yang sama dalam usaha mereka untuk mencapai apa yang dikehendakinya melalui jalan hukum......".

Uraian di atas, mengisyaratkan tentang keberadaan dan pelaksanaan program bantuan hukum, maka hal ini sebenarnya juga tidak dapat dilepaskan dengan sistem sosial yang ada. Yang dalam prakteknya ternyata juga turut mewarnai dalam menentukan pemberian bantuan hukum kepada masyarakat, khususnya masyarakat yang tergolong miskin

${ }^{6}$ Abdurrahman, Beberapa Aspek Tentang Bantuan Hukum di Indonesia, (Jakarta: UI, 1980), 17-18. 1988), 17.

7 Adnan Buyung Nasution. Bantuan Hukum di Indonesia, Jakarta: LP3ES. Ce.3,

348 JURNAL LISAN AL-HAL 
dan tidak mampu. Apabila demikian halnya, hukum yang dapat diharapkan dapat memberikan pengaturan secara adil.

Menurut Zulaidi bantuan hukum berasal dari istilah 'legal asisstance dan legal aid ${ }^{\prime \prime}$.

1. Legal aids biasanya digunakan untuk pengertian bantuan hukum dalam arti sempit berupa pemberian jasa dibidang hukum kepada orang yang terlibat dalam suatu perkara secara cuma-cuma atau gratis bagi mereka yang tidak mampu (miskin).

2. Legal assistance adalah istilah yang dipergunakan untuk menunjukkan pengertian bantuan hukum kepada mereka yang tidak mampu yang menggunakan honorarium.

Dalam praktek keduanya mempunyai orientasi yang berbeda satu sama lainnya. Sedangkan Clarence J. Dias mempergunakan istilah "legal service" yang diartikan dengan pelayanan hukum. Pelayanan hukum menurut Dias adalah "langkah-langkah yang diambil untuk menjamin agar operasi sistem hukum di dalam kenyataannya tidak akan menjadi diskriminatif sebagai adanya perbedaan tingkat penghasilan, kenyataan, dan sumber daya lain yang dikuasai oleh individu dalam masyarakat".

Dias menggunakan istilah pelayanan hukum karena pelayanan hukum akan mencakupi kegiatan seperti: pemberian bantuan hukum, pemberian bantuan untuk menekankan tuntutan agar sesuatu hak yang telah diakui oleh hukum akan tetapi selama ini tidak diimplementasikan, usaha agar kebijakan hukum dapat diimplementasikan. Dias mengartikan bantuan hukum sebagai: segala bentuk pemberian pelayanan oleh kaum profesi hukum kepada khalayak di masyarakat dengan maksud untuk menjamin agar tidak ada seorangpun di dalam masyarakat yang terampas haknya untuk memperoleh nasehat-nasehat hukum yang diperlukan hanya oleh karena sebab tidak dimilikinya sumber daya finansial yang cukup.

Dalam pemikiran Dias tersebut diatas, pelayanan hukum atau bantuan hukum akan mencakupi pelbagai macam kegiatan, yang meliputi:

1. Pemberian bantuan hukum;

2. Pemberian bantuan hukum untuk menekankan tututan agar sesuatu hak yang telah diakuinya oleh hukum akan tetapi selama ini tidak pernah diimplementasikan;

8 Yesmil Anwar dan Adang, Sistem Peradilan Pidana (Konsep, Komponen dan Pelaksanaannya Dalam Penegakkan Hukum di Indonesia), (Bandung: Widya Padjadjaran, 2009), 246. 
3. Usaha-usaha agar kebijakan-kebijakan hukum (legal policy) yang menyangkut kepentingan orang-orang miskin, dapat diimplementasikan secara lebih positif dan simpatik;

4. Usaha-usaha untuk meningkatkan kejujuran serta kelayakan prosedur di pengadilan dan di aparat-aparat lainnya yang menyelesaikan sengketa melalui usaha perdamaian;

5. Usaha-usaha untuk memudahkan pertumbuhan dan perkembangan hak-hak di bidang-bidang yang belum dilaksanakan atau diatur oleh hukum secara tegas; dan

6. Pemberian bantuan hukum yang diperlukan untuk menciptakan hubungan-hubungan kontraktual badan-badan hukum atau organisasiorganisasi kemasyarakatan yang sengaja dirancang untuk memaksimalkan kesempatan dan kemanfaatan yang telah diberikan oleh hukum.

Lokakarya bantuan hukum tingkat nasional tahun 1978, mengartikan Bantuan Hukum sebagai kegiatan pelayanan hukum yang diberikan kepada golongan yang tidak mampu (miskin) baik secara perorangan maupun kepada kelompok-kelompok masyarakat yang tidak mampu secara kolektif.

\section{Implementasi Bantuan Hukum}

Indonesia sebagai negara yang menganut paham negara hukum berdasarkan Pasal 1 ayat (3) UUD 1945 harus menjunjung tinggi hak asasi manusia dalam segala bentuk. Bentuk perlindungan terhadap hak asasi manusia, diantaranya adalah dengan memberi jaminan dan perlindungan agar setiap orang memiliki kedudukan yang sama di hadapan hukum dengan tidak ada pengecualiannya.

Adanya jaminan dan perlindungan tersebut memberikan petunjuk akan pentingnya bantuan hukum guna menjamin agar setiap orang dapat terlindungi hak-haknya dari tindakan hukum yang diskriminatif sehingga apa yang menjadi tujuan negara untuk menciptakan persamaan dihadapan hukum, dapat terlaksana karena berjalannya fungsi dari bantuan hukum tersebut ${ }^{9}$.

Bantuan hukum merupakan hal yang sangat esensial dalam menciptakan kehidupan yang adil serta melindungi hak asasi manusia dimana bantuan hukum

yang diberikan bertujuan untuk melindungi hak asasi masyarakat

${ }_{9}$ Bagir Manan, Menyongsong Otonomi Daerah, (Yogyakarta: Pusat Studi Hukum (PSH) Fakultas Hukum UII Yogyakarta, 2001), 59.

350 JURNAL LISAN AL-HAL 
dalam hal masalah hukum guna menghindari segala macam tindakan yang dapat membahayakan atau tindakan sewenang-wenang aparat penegak hukum atau aparat pemerintahan.

Berdasarkan Pasal 34 ayat (1) UUD 1945 ditegaskan bahwa "Fakir miskin dan anak-anak yang terlantar dipelihara oleh negara". Berdasarkan ketentuan Pasal 34 ayat (1) UUD 1945 tersebut negara mengakui hak ekonomi, sosial, budaya, sipil dan politik dari fakir miskin. Atas dasar pertimbangan tersebut, fakir miskin memiliki hak untuk diwakili dan dibela oleh advokat baik di dalam maupun di luar pengadilan (legal aid) sama seperti orang mampu yang mendapatkan jasa hukum dari advokat (legal service). Penegasan sebagaimana diambil dari Pasal 34 ayat (1) UUD 1945 memberikan implikasi bahwa bantuan hukum bagi fakir miskin pun merupakan tugas dan tanggungjawab negara dan merupakan hak konstitusional.

Undang-Undang yang mengatur tentang Bantuan Hukum diatur dalam UU No. 16 Tahun 2011 tentang Bantuan Hukum. UU No. 16 Tahun 2011 tentang Bantuan Hukum disepakati oleh DPR pada tanggal 4 Oktober 2011, kemudian Undang-Undang ini ditandatangani oleh Presiden Republik Indonesia Dr. Susilo Bambang Yudhoyono pada tanggal 31 Oktober 2011. Undang-Undang ini dicantumkan dalam lembaran Negara Republik Indonesia Tahun 2011 Nomor 104.

Adanya Undang-Undang Bantuan Hukum ini menjadi babak baru bagi upaya penegakan hukum yang lebih fair dan adil di Indonesia, khususnya bagi kelompok masyarakat yang tidak mampu. Undang-Undang ini telah menjadi impian sejak lama bagi para aktivis pengacara publik dan para pencari keadilan agar setiap proses dan tahapan dalam penegakan hukum dari sejak penyelidikan, penyidikan, dan persidangan di pengadilan setiap orang mendapatkan perlakuan secara manusiawi, dan mendapatkan akses yang sama terhadap bantuan hukum.

Dalam rangka mengimplementasikan UU Bantuan Hukum, setidaknya terdapat 5 peraturan pendukungnya, yaitu:

1. Peraturan Pemerintah No. 42 tahun 2013 Tentang Syarat dan Tata Cara Pemberian Bantuan Hukum dan Penyaluran Dana Bantuan Hukum.

2. Permenkumham No. 3 Tahun 2013 tentang Tata Cara Verifikasi dan Akreditasi Lembaga Bantaun Hukum;

3. Peraturan Mahkamah Agung Republik Indonesia Nomor 1 Tahun 2014 tentang Pedoman Pemberian Layanan Hukum Bagi Masyarakat Tidak Mampu di Pengadilan.

4. Keputusan Dirjen Badan Peradilan Umum Mahkamah Agung RI No. 52/DJU/SK/HK.006/5/Tahun 2014 tentang Petunjuk Pelaksanaan 
Peraturan Mahkamah Agung Republik Indonesia Nomor 1 Tahun 2014 tentang Pedoman Pemberian Layanan Hukum Bagi Masyarakat Tidak Mampu Di Pengadilan.

5. Permenkumham No. 1 Tahun 2018 tentang Paralegal dalam Pemberian Bantuan Hukum ditandatangani Menteri Hukum dan Hak Asasi Manusia Yasonna H. Laoly pada 17 Januari 2018. Permenkumham ini diundangkan dalam Berita Negara Republik Indonesia Tahun 2018 Nomor 182 oleh Widodo Ekatjahjana Dirjen Peraturan PerundangUndangan Kemenkumham RI pada 26 Januari 2018, di Jakarta.

Beberapa peraturan yang mengatur mengenai bantuan hukum yang berlaku setelah kemerdekaan Indonesia, antara lain: Pertama, Peraturan Menteri Kehakiman Republik Indonesia Nomor 1 Tahun 1965. Peraturan ini dikeluarkan atas dasar pertimbangan bahwa sebelum undang-undang tentang bantuan hukum terbentuk, perlu diadakan penertiban dalam pemberian bantuan hukum terutama oleh pokrol (pengacara praktek).

Kedua, Undang-Undang Nomor 14 Tahun 1970 Tentang KetentuanKetentuan Pokok Kekuasaan Kehakiman (Dicabut Dengan Undang-Undang Nomor 48 Tahun 2009 Tentang Kekuasaan Kehakiman). Dalam UU No. 14 Tahun 1970, masalah bantuan hukum diatur secara khusus dalam Bab VII Pasal 35 sampai dengan Pasal 38 (Abdurrahman, 1983: 84). Dalam ketentuan tersebut diatur suatu ketentuan mengenai bantuan hukum yang mengatur secara tegas adanya suatu jaminan bagi seseorang untuk memperoleh bantuan hukum dalam setiap tingkat pemeriksaan perkara pidana. Undang-Undang tersebut lebih lanjut menghendaki adanya suatu ketentuan-ketentuan tentang bantuan hukum yang berdiri sendiri dalam hukum acara pidana nasional. UU No. 14 Tahun 1970 kemudian dicabut dengan UU No. 4 Tahun 2004 Tentang Kekuasaan Kehakiman yang kemudian dicabut kembali dengan UU No. 48 Tahun 2009 Tentang Kekuasaan Kehakiman. Dalam UU No. 48 Tahun 2009, terdapat ketentuanketentuan baru mengenai bantuan hukum yang diatur dalam BAB XI Pasal 56 dan Pasal 57 yang menegaskan perlindungan terhadap hak rakyat miskin sebagai bentuk tanggungjawab negara.

Ketiga, UU No. 8 Tahun 1981 tentang Kitab Undang-Undang Hukum Acara Pidana (KUHAP). KUHAP bukanlah undang-undang yang mengatur khusus mengenai bantuan hukum, namun di dalamnya dimuat ketentuan mengenai bantuan hukum yang merupakan penjabaran lebih lanjut dari UU No. 14 Tahun 1970. Dalam pasal-pasal KUHAP yang mengatur mengenai bantuan hukum tersebut diatur mengenai hak memperoleh bantuan hukum, saat memberikan bantuan hukum, pengawasan 
pelaksanaan bantuan hukum, dan wujud dari bantuan hukum. Pasal 56 KUHAP secara tegas memberikan jaminan mengenai hak memperoleh bantuan hukum bagi tersangka/terdakwa yang: 1) Melakukan tindak pidana yang diancam dengan pidana mati atau ancaman pidana lima belas tahun atau lebih; dan 2) Tidak mampu secara ekonomi yang diancam dengan pidana lima tahun atau lebih yang tidak mempunyai penasehat hukum sendiri.

1. UU No. 18 Tahun 2003 tentang Advokat jo. PP No. 83 Tahun 2008 tentang Persyaratan dan Tata Cara Pemberian Bantuan Hukum CumaCuma. Sebagai salah satu pemberi bantuan hukum, maka seorang advokat wajib untuk memberikan bantuan hukum. Pasal 22 ayat (1) UU No. 18 Tahun 2003 tentang Advokat menegaskan bahwa advokat wajib memberikan bantuan hukum secara cuma-cuma kepada pencari keadilan yang tidak mampu. Selanjutnya untuk melaksanakan ketentuan Pasal 22 ayat (2), maka dibentuklah PP No. 83 Tahun 2008 tentang Persyaratan dan Tata Cara Pemberian Bantuan Hukum CumaCuma. Dalam hal pemberian bantuan cuma-cuma terhadap suatu perkara, perkara yang dapat dimintakan bantuan hukum cuma-cuma meliputi perkara di bidang pidana, perdata, tata usaha negara, dan pidana militer. Bantuan hukum secara cuma-cuma diberikan pula bagi perkara nonlitigasi (di luar pengadilan)

2. UU No. 16 Tahun 2011 Tentang Bantuan Hukum jo. PP No. 42 Tahun 2013 tentang Syarat dan Tata Cara Pemberian Bantuan Hukum dan Penyaluran Dana Bantuan Hukum. Lahirnya UU No. 16 Tahun 2011 tentang Bantuan Hukum menandakan untuk pertama kalinya di Indonesia bantuan hukum disusun dan dibuat dalam suatu tatanan yang teratur dan pasti sehingga diharapkan dapat mewujudkan keadilan dan persamaan kedudukan di muka hukum bagi rakyat miskin. Pasal 4 menentukan bahwa bantuan hukum yang diberikan meliputi masalah hukum keperdataan, pidana, dan tata usaha negara baik litigasi maupun nonlitigasi.

Pemberian bantuan hukum yang diberikan kepada penerima bantuan hukum meliputi perbuatan menjalankan kuasa, mendampingi, mewakili, membela, dan/atau melakukan tindakan hukum lain untuk kepentingan hukum penerima bantuan hukum. Ketentuan Pasal 15 ayat (5) dan Pasal 18 UU No. 16 Tahun 2011 menentukan syarat dan tata cara pemberian bantuan hukum dan penyaluran dana bantuan hukum akan diatur lebih lanjut dengan Peraturan Pemerintah. Untuk melaksanakan ketentuan tersebut, diundangkanlah PP No. 42 Tahun 2013 tentang Syarat dan Tata Cara Pemberian Bantuan Hukum dan Penyaluran Dana Bantuan 
Hukum. Peraturan tersebut mengatur mengenai syarat dan tata cara pendanaan serta pemberian bantuan hukum di Indonesia.

Kehadiran UU No. 16 Tahun 2011 tentang Bantuan Hukum membawa angin segar dalam sejarah bantuan hukum di Indonesia. Meskipun demikian, para pakar melihat bahwa masih ada kekurangan yang perlu disempurnakan dalam ketentuan Undang-Undang ini, antara lain:

1) Limitasi penerima bantuan hukum yang hanya terbatas pada masyarakat tidak mampu. Ketidakmampuan masyarakat harus dimaknai secara luas, bukan hanya tidak mampu secara ekonomi, tetapi juga ketidakmampuan dalam bidang sosial, politik, dan lain sebagainya sehingga penerima bantuan hukum tidak hanya sebatas mereka yang miskin secara materi, tetapi juga meliputi kelompok-kelompok masyarakat yang rentan seperti anak, perempuan, penyandang cacat, dan lain sebagainya.

2) Kewenangan tanpa batas penyelenggara bantuan hukum. Menurut UU No. 16 Tahun 2011, pemerintah dalam hal ini Kementerian Hukum dan HAM menjadi satu-satunya penyelenggara bantuan hukum yang memiliki kewenangan membuat kebijakan (regulating), melaksanakan (implementing), anggaran (budgeting), dan pengawasan (controlling). Melekatnya semua fungsi tersebut tidak lazim dan tidak sesuai dengan prinsip-prinsip pemerintahan yang baik (good governance), dan berpeluang menimbulkan penyalahgunaan wewenang (abuse of power).

3) Permasalahan verifikasi dan akreditasi. Perlu diketahui bahwa masalah verifikasi dan akreditasi harus dimaknai bukan sebagai proses legalisasi organisasi bantuan hukum melainkan hanya bagian dari prosedur untuk mendapatkan dana bantuan hukum dari pemerintah. Verifikasi dan akreditasi tidak boleh membatasi hak untuk memberikan bantuan hukum bagi masyarakat yang membutuhkan. Peraturan perundang-undangan harus menjamin bahwa organisasi bantuan hukum yang tidak ingin mengikuti verifikasi dan akreditasi (tidak mengakses dana pemerintah) tetap berhak untuk memberikan bantuan hukum dengan berpegang pada standar bantuan hukum.

4) Prosedur mendapatkan bantuan hukum. UU No. 16 Tahun 2011 mengatur sedemikian rupa syarat dan tata cara pemberian bantuan hukum. Akan tetapi, tidak selayaknya hak atas bantuan hukum terkalahkan oleh persoalan administratif. Seharusnya Undang-Undang dan peraturan pelaksanannya memberikan kemudahan-kemudahan agar seseorang yang betul-betul memenuhi kualifikasi miskin dapat

$354 \mid$ JURNAL LISAN AL-HAL 
mengakses bantuan hukum tanpa terhambat dengan persoalanpersoalan administratif (Point Krusial Implementasi UU Bantuan Hukum ${ }^{10}$.

Bantuan hukum menjadi salah satu upaya untuk mendorong pelaksanaan hak-hak warga negara dalam menjalani proses hukum. Bantuan hukum juga berpeluang dapat mencegah terjadinya pelanggaran terhadap hak-hak hukum individu yang sudah diatur dalam peraturan perundang-undangan maupun instrumen hukum internasional. Pengaturan bantuan hukum dalam undang-undang tersendiri merupakan salah satu bentuk penegasan terhadap hak masyarakat atas bantuan hukum dan pengaturan lebih lanjut jaminan hak konstitusional warga negara yang telah diatur dalam UUD 1945.

Angka pelanggaran hak individu dalam proses hukum yang masih tinggi dan cenderung meningkat, termasuk pasca pengesahan UU Bantuan Hukum ini membutuhkan pemberian bantuan hukum baik melalui sistem bantuan hukum yang dikelola oleh pemerintah maupun melalui mekanisme lain. Pelaksanaan bantuan hukum melalui program bantuan hukum pemerintah masih memiliki keterbatasan sehingga belum dapat menjamin penghormatan terhadap hak-hak individu atau mencegah terjadinya tindakan kekerasan dalam porses hukum baik di tingkat penyelidikan, penyidikan, penuntutan dan pelaksanaan putusan hakim.

Potensi penerima bantuan hukum jumlahnya sangat besar, namun sistem bantuan hukum yang dijalankan saat ini belum sesuai dengan kebutuhan riil terhadap bantuan hukum. Proses yang terjadi pada awal implementasi bantuan hukum ini terlihat sebagai pemenuhan kewajiban pemerintah yang sudah ditentukan oleh undang-undang tanpa mempertimbangkan efektivitas dan kualitas implementasinya. Salah satu persoalan mendasar mengenai pengaturan kelembagaan pengelolaan bantuan hukum adalah adanya sentralisasi peran dan kewenangan ke dalam satu lembaga dalam mengatur, mengelola dan mengawasi implementasi bantuan hukum berpotensi menimbulkan kelemahan sistem bantuan hukum dan penyalahgunaan atau penyimpangan kewenangan. Keberadaan program Criminal Defence Lawyer_CDL (penanganan perkara pidana) memiliki peran yang signifikan dalam memberikan layanan bantuan hukum kepada masyarakat dalam perkara pidana. Hal ini juga didukung dengan kondisi masih tingginya angka pelanggaran hak individu dalam proses hukum. Adanya pengembangan unit khusus di tiap-tiap

10 http://www.pbhi.or.id/berita/point-krusial-implementasi-uu-bantuan-hukum, pada tanggal 15 Maret 2018, pukul 20.00. 
organisasi pemberi bantuan hukum juga dapat menjadi salah satu upaya dalam memperluas akses bantuan hukum bagi masyarakat.

Implementasi bantuan hukum sesuai dengan UU Bantuan Hukum pada tahun awal ini telah menciptakan kondisi baru dalam pelaksanaan sistem bantuan hukum yaitu dengan hadirnya institusi negara melalui pendanaan. Relasi antara pemberi bantuan hukum dengan pemerintah ini berimplikasi pada prosedur administrasi yang harus dijalani oleh organisasi pemberi bantuan hukum. Pada beberapa kondisi, pemenuhan persyaratan administrasi ini menyulitkan organisasi pemberi bantuan hukum. Sehingga menimbulkan keengganan lembaga untuk mengikuti program tersebut.

Keberadaan progam bantuan hukum yang merupakan implementasi UU Bantuan Hukum belum sepenuhnya dipahami oleh aparat penegak hukum. Sistem bantuan hukum yang dijalankan oleh aparat penegak hukum masih mengacu pada ketentuan peraturan perundang-undangan yang lama.

Minimnya pemahaman terhadap aturan bantuan hukum yang baru ini juga berimplikasi pada persoalan koordinasi dalam pelayanan bantuan hukum selama proses hukum dijalankan. Kondisi ini, di satu sisi, menunjukkan bahwa respon terhadap sistem bantuan hukum lebih banyak berasal dari organisasi pemberi bantuan hukum dibandingkan dengan aparat penegak hukum. Di sisi lain, beberapa lembaga juga belum menyesuaikan program bantuan hukumnya dengan ketentuan UU Bantuan Hukum.

Akses terhadap program bantuan hukum bagi masyarakat masih terbatas terutama karena minimnya keberadaan organisasi pemberi bantuan hukum atau akses wilayah yang sulit dicapai secara geografis. Di sisi lain, fasilitasi dalam bentuk dukungan dana bagi organisasi bantuan hukum ini juga menyimpan persoalan bagi efektivitas pelaksanaan bantuan hukum mengingat perbandingan dukungan dana dengan kebutuhan dalam pemberian bantuan hukum yang tidak sebanding. Selain ketidakcukupannya dalam memenuhi kebutuhan pemberian bantuan hukum, pendanaan ini juga tidak dapat memberikan kontribusi bagi keberlanjutan organisasi pemberi bantuan hukum, terutama bagi organisasi yang mandiri atau tidak terafiliasi dengan organisasi lainnya.

Pengembangan layanan bantuan hukum juga menjadi program kerja di beberapa pemerintah daerah. Inisiatif ini perlu direspon oleh pemerintah untuk mengefektifkan pemberian layanan bantuan hukum dan 
memperluas akses masyarakat untuk mendapatkna bantuan hukum ${ }^{11}$.

Das sein, das solen. Apa yang diharapkan seringkali tidak sesuai dengan kenyataan yang ada. UU No. 16 Tahun 2011 tentang Bantuan Hukum beserta peraturan pelaksanaannya, PP No. 42 Tahun 2013 tentang Syarat dan Tata Cara Pemberian Bantuan Hukum dan Penyaluran Dana Bantuan Hukum, diundangkan dengan harapan peraturan tersebut dapat menjadi dasar bagi negara untuk menjamin warga negaranya, khususnya bagi orang atau kelompok orang miskin, untuk mendapatkan akses keadilan dan persamaan hak di hadapan hukum. Namun bagaimanakah implementasinya?

Untuk menjawab pertanyaan tersebut, penulis coba mengidentifikasi hal-hal yang menunjukkan bahwa implementasi UndangUndang Bantuan Hukum belum sesuai harapan, antara lain sebagai berikut:

1. Terkait pihak yang berhak menerima bantuan hukum yaitu kelompok masyarakat miskin (dalam hal perkara pidana) adalah mereka (orang miskin) yang diancam dengan pidana paling sedikit 5 (lima) tahun, berarti bagi mereka yang diancam pidana kurang dari 5 (lima) tahun tidak berhak menerima bantuan hukum. Ditambah lagi, bahwa penerima bantuan hukum berdasarkan UU No. 16 Tahun 2011 tentang Bantuan Hukum hanyalah terbatas pada orang atau kelompok orang miskin saja. Padahal menurut UUD 1945 Pasal 27 ayat (1) dan Pasal 28D ayat (1), serta UU No. 39 Tahun 1999 tentang HAM Pasal 5 ayat (3), penerima bantuan hukum adalah setiap warga masyarakat tanpa terkecuali, termasuk didalamnya adalah kelompok masyarakat rentan.

2. Bagi pelaku tindak pidana ada bantuan hukum, mengapa bagi korban tindak pidana tidak ada bantuan hukum (dalam arti luas)?. Selama ini hak untuk mendapatkan bantuan hukum itu hanya diperuntukkan bagi pihak pelaku tindak pidana. Hal ini mestinya harus menjadi perhatian serius dalam pengaturannya, agar sinkron dengan amanat konstitusi tentang persamaan hak di depan hukum dan pengadilan.

3. Ruang lingkup bantuan hukum hanya terbatas pada masalah hukum keperdataan, pidana dan tata usaha negara baik litigasi maupun nonlitigasi. Bagaimana dengan masalah atau kasus hak konstitusional warga negara yang hendak dimintakan masyarakat miskin dan marginal tentang judicial review ke Mahkamah Konstitusi atau sengketa informasi ke Komisi Informasi Publik.

11 Sri Suparyati,dan M. Yasin, Ed. Bantuan Hukum Masih Sulit Diakses, Jakarta: KontraS, 2014), 69. 


\section{Hambatan dan Kendala Implementasi Bantuan Hukum}

Komponen struktur adalah bagian-bagian yang bergerak dalam mekanisme misalnya pengadilan. Komponen substansi merupakan hasil aktual yang diterbitkan oleh sistem hukum dan meliputi pula kaidahkaidah hukum yang tidak tertulis. Sedangkan komponen struktur nilai dan sikap yang mengikat sistem hukum itu secara bersamaan dan akan menghasilkan suatu bentuk penyelenggaraan hukum dalam budaya masyarakat secara keseluruhan yang menganut sistem keadilan, kepastian hukum serta segi kemanfaatan. Dalam hal keberhasilan penegakan hukum bukan semata-mata hanya mengandalkan perundang-undangan saja, disana terdapat faktor-faktor lain yang mempengaruhinya. Ada faktor positif tetapi banyak pula faktor negatif yang notabene merupakan faktor penghambat program jaminan bantuan hukum.

Faktor-faktor penghambat dalam upaya penegakan hukum itu antara lain adalah sebagai berikut:

1. Faktor hukumnya sendiri, yaitu berkaitan dengan undang-undang dan regulasi yang mengatur pelaksanaannya secara jelas.

2. Faktor penegak hukum, yakni pihak-pihak yang membantu maupun menerapkan hukum, dalam hal ini penegak hukum belum berani melakukan terobosan serta dari segi kualitas yang belum memadai.

3. Faktor sarana atau fasilitas yang mendukung penegakan hukum dapat berupa operasional dan sebagainya.

4. Faktor masyarakat, yakni lingkungan dimana hukum tersebut berlaku atau diterapkan disesuaikan dengan faktor-faktor yang mempengaruhinya.

5. Faktor kebudayaan, yakni sebagai hasil karya, cipta, dan rasa yang didasarkan pada karsa manusia didalam pergaulan hidup ${ }^{12}$.

\section{Point Krusial Implementasi UU Bantuan Hukum.}

Menurut laporan Forum Akses Keadilan untuk Semua (FOKUS) yang terdiri dari LBH Jakarta, LBH APIK, PBHI, ILRC, LBH Pers, Perkumpulan Huma, LBH ASPEK, LKBH FH UNKRIS, LKBH FH UPH, LKBH FH UNPAD, Forum Warga Kota Jakarta (FAKTA), Arus Pelangi, dan Rumah Singgah Master Depok. Pada Konfrensi persnya FOKUS, memandang terdapat setidaknya lima point krusial dalam implementasi bantuan hukum pasca disahkannya UU No. 16 Tahun 2011 tentang Bantuan Hukum, yakni:

12 Soerjono Soekanto dan Sri Mamuji, Penelitian Hukum Normatif Suatu Tinjauan Singkat, (Jakarta: CV.Rajawali, 1986), 15.

358 JURNAL LISAN AL-HAL 
Pertama, mengenai Limitasi Penerima Bantuan Hukum yang hanya terbatas pada masyarakat tidak mampu. FOKUS memandang Ketidakmampuan masyarakat harus dimaknai secara luas, bukan hanya tidak mampu secara ekonomi, tetapi juga ketidakmampuan dalam bidang sosial, politik, dan lain sebagainya. Sehingga penerima bantuan hukum tidak hanya sebatas mereka yang miskin secara materi, tetapi juga meliputi kelompok-kelompok masyarakat yang rentan seperti anak, perempuan, penyandang cacat, dan lain sebagainya. Peraturan Pemerintah perlu mengatur lebih rinci tentang kriteria tidak mampu bagi masyarakat, dimana tidak hanya berdasarkan kriteria miskin tetapi juga karena adanya kepentingan keadilan yang menghendakinya. Fakta menunjukkan, organisasi bantuan hukum selama ini tidak hanya menangani kasus-kasus orang miskin, tetapi juga kelompok rentan, seperti disebutkan di atas.

Kedua, mengenai Kewenangan tanpa Batas Penyelenggara Bantuan Hukum. Menurut UU Bantuan Hukum pemerintah dalam hal ini Kementerian Hukum dan HAM menjadi satu-satunya penyelenggara bantuan hukum, yang memiliki kewenangan membuat kebijakan (regulating), melaksanakan (implementing), anggaran (budgeting), dan pengawasan (controlling). Melekatnya semua fungsi tersebut tidak lazim dan tidak sesuai dengan prinsip-prinsip pemerintahan yang baik (good governance), dan berpeluang menimbulkan penyalahgunaan wewenang (abuse of power). FOKUS berharap Peraturan Pemerintah harus menjamin bahwa implementasi dan penyelenggaraan bantuan hukum dilaksanakan secara transparan, akuntabel, dan memenuhi rasa keadilan para pencari keadilan (justice seeker).

Ketiga, Permasalahan Verifikasi dan Akreditasi. FOKUS mengingatkan, Verifikasi dan Akreditasi harus dimaknai bukan sebagai proses legalisasi organisasi bantuan hukum, melainkan hanya bagian dari prosedur untuk mendapatkan dana bantuan hukum dari pemerintah. Verifikasi dan akreditasi tidak boleh membatasi hak masyarakat untuk memberikan bantuan hukum bagi masyarakat yang membutuhkan. Peraturan Pemerintah atau Peraturan Menteri harus menjamin, bahwa organisasi bantuan hukum yang tidak ingin mengikuti verifikasi dan akreditasi (tidak mengakses dana pemerintah), atau tidak lolos verifikasi dan akreditasi tetap berhak untuk memberikan bantuan hukum dengan berpegang pada standar bantuan hukum.

Keempat, Pemberi Bantuan Hukum yang seakan-akan dimonopoli Advokat. Undang-Undang Bantuan Hukum menyebutkan empat elemen yang dapat memberikan bantuan hukum, yaitu; advokat, dosen, paralegal dan mahasiswa hukum. Keempat elemen tersebut oleh UU dijamin 
menjadi bagian dari kegiatan bantuan hukum dan mereka akan bekerja dibawah organisasi bantuan hukum. Peraturan Pemerintah tidak perlu lagi membatasi bahwa yang dapat memberikan bantuan hukum hanyalah advokat, tetapi yang perlu dilakukan adalah memperjelas ruang lingkup kerja masing-masing dalam memberikan bantuan hukum. Selain itu, PP juga perlu memperjelas beberapa kriteria pemberi bantuan hukum seperti legalitas LKBH yang ada di perguruan tinggi, ataupun lembaga bantuan hukum yang dibuat oleh organisasi kemasyarakatan seperti serikat buruh dan sebagainya.

Kelima, mengenai Prosedur Mendapatkan Bantuan Hukum. Undang-Undang Bantuan Hukum mengatur sedemikian rupa syarat dan tata cara pemberian bantuan hukum. Tidak selayaknya hak atas bantuan hukum terkalahkan oleh persoalan administrative. Oleh karena itu, untuk memperkuat akses masyarakat tidak mampu terhadap bantuan hukum, Peraturan Pemerintah yang akan disusun diharapkan memberikan kemudahan-kemudahan agar seseorang yang betul-betul memenuhi kualifikasi miskin dapat mengakses bantuan hukum tanpa terhambat dengan persoalan-persoalan administratif ${ }^{13}$.

Berdasarkan hasil penelitian, kita dapat melihat bahwa sejak lahirnya UU No. 16 Tahun 2011 tentang Bantuan Hukum sampai dengan saat ini, penerapan bantuan hukum pro bono publico, masih sangat kurang dan perlu dikembangkan lagi. Masih banyak kendala dalam melaksanakan bantuan hukum. Hal ini perlu menjadi perhatian bagi pemerintah untuk mengambil tindakan guna memperbaiki kekurangan-kekurangan tersebut.

Pemenuhan hak atas bantuan hukum mempunyai arti bahwa negara harus menggunakan seluruh sumberdayanya termasuk dalam bidang eksekutif, legislatif dan administratif untuk mewujudkan hak atas bantuan hukum secara progresif. Negara seharusnya membuat tindakan dengan membuat kebijakan bantuan hukum dalam perspektif acces to justice. Sejatinya, sudah seharusnya pemerintah mulai serius dalam membuat serta menumbuhkan sebuah gerakan bantuan hukum, salah satunya dengan membuat regulasi yang mampu mangatur secara efektif program bantuan hukum terutama terhadap si terpidana yang cenderung diabaikan bahkan diacuhkan. Dalam rangka perhormatan, pengakuan dan penegakan atas hukum dan HAM maka arah kebijakan ditujukan kepada peningkatan pemahaman, menciptakan penegakan dan kepastian hukum yang konsisten terhadap nilai-nilai Hak Asasi Manusia dengan menunjukkan perilaku yang adil dan tidak diskriminatif. Penyelenggaraan

13 www.pbhi.or.id, diakses: 15 Maret 2018.

$360 \mid$ JURNAL LISAN AL-HAL 
bantuan hukum yang tidak serius merupakan pelanggaran Hak Asasi Manusia yang berarti bertentangan dengan hak konstitusional warga negaranya.

Jadi yang menjadi penghalang penerapan bantuan hukum ini diantaranya juga adanya peranan negara yang kurang menjalankan kewajibanya, dalam memberikan jaminan atas batuan hukum, jaminan dalam arti mengawal pelaksanaan hak-hak tersangka atau terdakwa yang terdapat didalam undang-undang. Jadi walaupun hak-hak atas bantuan hukum ini sudah ada di dalam undang-undang, tidak semestinya pemerintah lengah terhadap penerapan bantuan hukum khususnya bagi masyarakat yang tidak mampu. Disamping adanya faktor penghambat lain yaitu kurangnya kesadaran hukum aparat penegak hukum dalam menjalankan tugasnya, baik ditingkat penyidikan, penuntutan, persidangan pengadilan, maupun penerapan hukuman, yang melakukan tugasnya dengan sewenang-wenang sehingga banyaknya korban dari perlakuan aparat penegak hukum tersebut.

Dengan adanya kesadaran dari para penegak hukum dan kerja sama antara negara dan para penegak hukum yang digalang dengan baik, serta dengan adanya sosialisasi kepada masyarakat luas, terutama masyarakat miskin, niscaya tujuan negara Indonesia sebagai negara hukum dalam rangka mewujudkan keadilan dan persamaan di depan hukum guna tercapainya masyarakat yang adil dan makmur dapat segera terwujud di Indonesia.

Secara umum, Problematika yang dihadapi terkait implementasi pemberian Bantuan Hukum kepada masyarakat miskin dalam rangka mencari keadilan berdasarkan UU No. 16 Tahun 2011 tentang Bantuan Hukum dapat diklasifikasi dan dibedakan menjadi 3 (tiga) faktor, yakni; faktor substansi hukum (legal substance), struktur hukum (legal structure), dan budaya hukum (legal culture):

1. Faktor substansi hukum yang menghambat salah satunya adalah kekurangan atau kelemahan dalam substansi Pasal 56 ayat (1) KUHAP yang mengatur mengenai pembatasan penerima bantuan hukum berdasarkan kualifikasi ancaman hukuman. Faktor struktur hukum yang menghambat yakni, faktor penegak hukum dari segi internal dan eksternal yang juga meliputi sarana atau fasilitas. Faktor penegak hukum dari segi internal yang menghambat seperti, kurangnya integritas, moralitas, idealisme dan profesionalitas advokat. Faktor penegak hukum dari segi eksternal dan sarana atau fasilitas yang menghambat seperti kurangnya Lembaga Bantuan Hukum yang lulus diakreditasi oleh Kementerian Hukum dan HAM dan kurangnya JURNAL LISAN AL-HAL $\mid 361$ 
advokat yang profesional, kurangnya pendanaan atau anggaran dari Pemerintah Daerah, kurangnya kontrol dan pengawasan. Faktor budaya hukum yang menghambat meliputi faktor budaya hukum atau faktor kebudayaan dan faktor masyarakat itu sendiri.

2. Faktor budaya hukum atau kebudayaan dalam hal ini meliputi faktor budaya hukum atau kebudayaan dari masyarakat dan penegak hukum (penyidik dan advokat). Seperti, kurangnya pemahaman masyarakat terhadap hak atas bantuan hukum mengacu pada ketidakpercayaan, sikap pesimisme, serta sikap skeptis terhadap pelaksanaan bantuan hukum, dan elemen sikap, nilai-nilai, cara bertindak dan berpikir advokat dan penyidik, yang terjadi secara berulang-ulang sehingga mengarah pada sikap atau tindakan penyimpangan.

3. Faktor masyarakat yang menghambat adalah pandangan masyarakat yang negatif tentang pelaksanaan bantuan hukum serta kekhawatiran dalam menggunakan bantuan hukum.

\section{Simpulan}

Setelah melakukan penelitian dan pembahasan data yang diperoleh dalam penelitian ini, maka sebagai penutup dari pembahasan atas permasalahan, penulis dapat menarik beberapa kesimpulan sebagai berikut: Pertama, Implementasi Bantuan Hukum pada masyarakat miskin sampai sejauh ini belum cukup optimal. Pelaksanaan bantuan hukum melalui program bantuan hukum pemerintah masih memiliki keterbatasan sehingga belum dapat menjamin penghormatan terhadap hak-hak individu masyarakat miskin. Hal ini disebabkan antara lain:

1. Potensi penerima bantuan hukum jumlahnya sangat besar, namun sistem bantuan hukum yang dijalankan saat ini belum sesuai dengan kebutuhan riil terhadap bantuan hukum.

2. Implementasi bantuan hukum sesuai dengan UU Bantuan Hukum pada saat ini telah menciptakan kondisi baru dalam pelaksanaan sistem bantuan hukum yaitu dengan hadirnya institusi negara melalui pendanaan. Relasi antara pemberi bantuan hukum dengan pemerintah ini berimplikasi pada prosedur administrasi yang harus dijalani oleh organisasi pemberi bantuan hukum. Pada beberapa kondisi, pemenuhan persyaratan administrasi ini menyulitkan organisasi pemberi bantuan hukum. Sehingga menimbulkan keengganan lembaga untuk mengikuti program tersebut.

3. Keberadaan progam bantuan hukum yang merupakan implementasi UU Bantuan Hukum belum sepenuhnya dipahami oleh aparat penegak 
hukum dalam menjalankan tugasnya, baik ditingkat penyidikan, penuntutan, persidangan di pengadilan, maupun penerapan hukuman. Sistem bantuan hukum yang dijalankan oleh aparat penegak hukum masih mengacu pada ketentuan peraturan perundang-undangan yang lama.

4. Akses terhadap program bantuan hukum bagi masyarakat masih terbatas terutama karena minimnya keberadaan organisasi pemberi bantuan hukum atau akses wilayah yang sulit dicapai secara geografis.

5. Keberadaan fasilitasi dalam bentuk dukungan dana bagi organisasi bantuan hukum masih menyimpan persoalan bagi efektivitas pelaksanaan bantuan hukum mengingat perbandingan dukungan dana dengan kebutuhan dalam pemberian bantuan hukum yang tidak sebanding. Selain ketidakcukupannya dalam memenuhi kebutuhan pemberian bantuan hukum, pendanaan ini juga tidak dapat memberikan kontribusi bagi keberlanjutan organisasi pemberi bantuan hukum, terutama bagi organisasi yang mandiri atau tidak terafiliasi dengan organisasi lainnya.

Kedua, Problematika yang dihadapi terkait implementasi pemberian Bantuan Hukum kepada masyarakat miskin dalam rangka mencari keadilan berdasarkan UU No. 16 Tahun 2011 tentang Bantuan Hukum secara umum dapat diklasifikasi dan dibedakan menjadi 3 (tiga) faktor yakni; faktor substansi hukum (legal substance), struktur hukum (legal structure), dan budaya hukum (legal culture):

1. Faktor substansi hukum yang menghambat salah satunya adalah kekurangan atau kelemahan dalam substansi Pasal 56 ayat (1) KUHAP yang mengatur mengenai pembatasan penerima bantuan hukum berdasarkan kualifikasi ancaman hukuman. Faktor struktur hukum yang menghambat yakni, faktor penegak hukum dari segi internal dan eksternal yang juga meliputi sarana atau fasilitas. Faktor penegak hukum dari segi internal yang menghambat seperti, kurangnya integritas, moralitas, idealisme dan profesionalitas advokat. Faktor penegak hukum dari segi eksternal dan sarana atau fasilitas yang menghambat seperti kurangnya Lembaga Bantuan Hukum yang lulus diakreditasi oleh Kementerian Hukum dan HAM dan kurangnya advokat yang profesional, kurangnya pendanaan atau anggaran dari Pemerintah Daerah, kurangnya kontrol dan pengawasan. Faktor budaya hukum yang menghambat meliputi faktor budaya hukum atau faktor kebudayaan dan faktor masyarakat itu sendiri.

2. Faktor budaya hukum atau kebudayaan dalam hal ini meliputi faktor budaya hukum atau kebudayaan dari masyarakat dan penegak hukum 
(penyidik dan advokat). Seperti, kurangnya pemahaman masyarakat terhadap hak atas bantuan hukum mengacu pada ketidakpercayaan, sikap pesimisme, serta sikap skeptis terhadap pelaksanaan bantuan hukum, dan elemen sikap, nilai-nilai, cara bertindak dan berpikir advokat dan penyidik, yang terjadi secara berulang-ulang sehingga mengarah pada sikap atau tindakan penyimpangan.

3. Faktor masyarakat yang menghambat adalah pandangan masyarakat yang negatif tentang pelaksanaan bantuan hukum serta kekhawatiran dalam menggunakan jasa bantuan hukum.

\section{DAFTAR PUSTAKA}

Abdurrahman, Beberapa Aspek Tentang Bantuan Hukum di Indonesia, UI, Jakarta. 1980.

-----------, Aspek-Aspek Bantuan Hukum di Indonesia, Cendana Press, Jakarta. 1983.

Amiruddin dan Zainal Asikin, Pengantar Metode Penelitian Hukum, PT Raja Grafindo Persada, Jakarta. 2004.

Anwar, Yesmil dan Adang, Sistem Peradilan Pidana (Konsep, Komponen dan Pelaksanaannya Dalam Penegakkan Hukum di Indonesia). Bandung: Widya Padjadjaran, 2009.

Asshiddiqie, Jimly, Konsolidasi Naskah UUD 1945 setelah Perubahan Keempat, Depok, Pusat Studi Hukum Tata Negara Fakultas Hukum Universitas Indonesia, Jakarta. 2002.

Asshiddiqie, Jimly, Hak Konstitusional Perempuan dan Tantangan Penegakannya, disampaikan pada acara Dialog Publik dan Konsultasi Nasional Komnas Perempuan "Perempuan dan Konstitusi di Era Otonomi Daerah: Tantangan dan Penyikapan Bersama”, Jakarta, 27 November 2007.

Bagir Manan, Menyongsong Otonomi Daerah, Pusat Studi Hukum (PSH) Fakultas Hukum UII Yogyakarta. 2001.

Gemma Noor Febryana, http://hukumpedia.com/ham/sebuah-kritikterhadap-undang-undang-bantuanhukum-hk5260f92232f57.html. Diakses, 15 Maret 2018

Ibrahim, Jhony, Teori dan Metodologi Penelitian Hukum Normatif, Bayumedia Publishing, Surabaya. 2005.

Keputusan Direktur Jenderal Badan Peradilan Umum Mahkamah Agung Republik Indonesia Nomor : 52/DJU/SK/HK.006/5/Tahun 2014 tentang Petunjuk Pelaksanaan Peraturan Mahkamah Agung Republik

$364 \mid$ JURNAL LISAN AL-HAL 
Indonesia Nomor 1 Tahun 2014 tentang Pedoman Pemberian Layanan Hukum Bagi Masyarakat Tidak Mampu Di Pengadilan. 2014 Kusumah, Mulyana W, Paralegal dan Akses Masyarakat Terhadap Keadilan, Yayasan Obor Indonesia YLBHI, Jakarta. 1991.

-------------, dalam Kelompok Kerja Keparalegalan Indonesia, Analisis Kritik RUU Bantuan Hukum, Pokja Paralegal, Jakarta. 2011.

LBH Tak Berbadan Hukum Boleh Ikut Verifikasi.Http//HukumOnline.Com/Akses, 15 Maret 2018

Lubis, T. Mulya, Bantuan Hukum dan Kemiskinan Struktural. Jakarta: LP3ES. 1986.

MK Putuskan Paralegal Boleh Beri Bantuan Hukum, www.GresNews.Com, Diakses, 15 Maret 2018

Nasution, Adnan Buyung, Bantuan Hukum di Indonesia, Ce.3. Jakarta: LP3ES. 1988.

Peraturan Mahkamah Agung Republik Indonesia Nomor 1 Tahun 2014 tentang Pedoman Pemberian Layanan Hukum Bagi Masyarakat Tidak Mampu Di Pengadilan. 2014.

Peraturan Menteri Hukum dan Hak Asasi Manusia RI Nomor 22 Tahun 2013 tentang Peraturan Pelaksanaan Peraturan Pemerintah RI Nomor 42 Tahun 2013 tentang Syarat dan Tata Cara Pemberian Bantuan Hukum dan Penyaluran Dana Bantuan Hukum. 2013.

Peraturan Menteri Hukum dan Hak Asasi Manusia RI Nomor 3 Tahun 2013 tentang Tata Cara Verifikasi dan Akreditasi Lembaga Bantuan Hukum atau Organisasi Kemasyarakatan. 2013.

Peraturan Pemerintah Nomor 42 Tahun 2013 tentang Syarat dan Tata

Cara Pemberian Bantuan Hukum dan Penyaluran Dana Bantuan Hukum. 2013.

Peraturan Pemerintah Nomor 83 Tahun 2008 tentang Persyaratan dan Tata Cara Pemberian Bantuan Hukum secara Cuma-Cuma. 2008.

PERMA Nomor 1 Tahun 2014 tentang Pedoman Pemberian Layanan Bantuan Hukum Bagi Masyarakat Tidak Mampu di Pengadilan. 2014.

PERMA Nomor 1 Tahun 2014 tentang Pedoman Pemberian Layanan Bantuan Hukum Bagi Masyarakat Tidak Mampu di Pengadilan. 2014.

Permenkumham Nomor 1 Tahun 2018 tentang Paralegal dalam Pemberian Bantuan. 2018.

Point Krusial Implementasi UU Bantuan Hukum, (www.pbhi.or.id, Diakses: 15 Maret 2018.

Point Krusial Implementasi UU Bantuan Hukum, http://www.pbhi.or.id/berita/point-krusial-implementasi-uubantuan-hukum, Diakses, 15 Maret 2018. 
Soekanto, Soerjono dan Mamuji, Sri, Penelitian Hukum Normatif Suatu Tinjauan Singkat, CV.Rajawali, Jakarta. 1986.

Suparyati, Sri dan M. Yasin, Ed., Bantuan Hukum Masih Sulit Diakses, KontraS, Jakarta. 2014.

Undang-Undang Dasar Republik Indonesia Tahun 1945.

Undang-Undang Nomor 16 Tahun 2011 tentang Bantuan Hukum.

Undang-Undang Nomor 39 Tahun 1999 tentang Hak Asasi Manusia

Undang-Undang Nomor 48 Tahun 2009 tentang Kekuasaan Kehakiman.

Undang-Undang Nomor 49 Tahun 2009 tentang Peradilan Umum.

Undang-Undang Nomor 50 Tahun 2009 tentang Perubahan Kedua Atas Undang-Undang Kekuasaan Kehakiman

Undang-Undang Nomor18 Tahun 2003 tentang Advokat

Winarta, Frans Hendra, Advokat Indonesia-Citra, Idealisme, dan Keprihatinan. Jakarta: Pustaka Sinar Harapan. 1995.

YLBHI dan AusAID, Panduan Bantuan Hukum Di Indonesia, YLBHI, Jakarta. 2014. 